\title{
Article \\ Planning the Ideal Refugee Camp? A Critical Interrogation of Recent Planning Innovations in Jordan and Germany
}

\author{
Ayham Dalal *, Amer Darweesh, Philipp Misselwitz and Anna Steigemann \\ Department of International Urbanism and Design, Technical University of Berlin, 10623 Berlin, Germany; E-Mails: \\ a.dalal@tu-berlin.de (A.D.), amerjdar@gmail.com (A.D.), misselwitz@tu-berlin.de (P.M.), a.steigemann@tu-berlin.de (A.S.) \\ * Corresponding author
}

Submitted: 27 August 2018 | Accepted: 21 November 2018 | Published: 20 December 2018

\begin{abstract}
With the increase of refugee movements since 2014 in Europe and the Near East, the debate of how to plan appropriate shelters and emergency accommodation has gained a new momentum. Established techno-managerial approaches have been criticised as inappropriate, and the professional community of planners and architects was increasingly drawn into debates for alternative solutions. This article traces the "innovations" that promise better, more effective, and more humane emergency shelters using the examples of the "Tempohomes" in Berlin as well as the Jordanian refugee camps of Zaatari and Azraq. In both cases, planners were employed to address the ambivalent reality of protracted refugee camps and include "lessons" from failures of earlier solutions. While the article acknowledges the genuine attempt of planners to engage with the more complex needs and expectations of refugees, a careful look at the results of the planning for better camps reveals ambivalent outcomes. As camps acquire a new visual appearance, closer to housing, which mixes shelter design with social spaces and services as essential parts of the camp; these "innovations" bear the danger of paternalistic planning and aestheticisation, camouflaging control under what seems to be well-intended and sensitive planning. The article focuses on refugees' agency expressed in critical camp studies to interrogate the planning results. While recent critical refugee studies have demanded recognition of refugees as urban actors which should be included in the co-production of the spatial reality of refugee accommodations, new planning approaches tend to result in a shrinking of spaces of selfdetermination and self-provisioning of refugees.
\end{abstract}

\section{Keywords}

agency; asylum; control; design; innovation; migration; refugee camps; urban planning

\section{Issue}

This article is part of the issue "European Cities Planning for Asylum", edited by Frank Eckardt (Bauhaus-Universität Weimar, Germany).

(C) 2018 by the authors; licensee Cogitatio (Lisbon, Portugal). This article is licensed under a Creative Commons Attribution 4.0 International License (CC BY).

\section{Refugees as Urban Actors: The Humanitarian Technocratic Planning and the Concepts of Agency and Control in Refugee Camps}

Relief organisations and governments often perceive refugees in numbers. The urge to make decisions about how to deal with the "waves of refugees" crossing borders can be very daunting. This results in a wide variety of humanitarian and governmental policies, programs, and responses aiming to contain the aftermath of mass displacements haunting the security and safety of receiving countries. Through techno-managerial arrangements, which tailor generic emergency manuals, guidelines, and policies with the agendas of host governments and other powers, humanitarian organisations seek the best possible pragmatic response to a specific crisis.

Critical camp studies have looked at these responses from the perspective of refugees that feature in official response strategies primarily as passive victims and beneficiaries. How techno-managerial arrangements have 
the potential to result in de-humanising, exploitative power systems has fuelled numerous critiques. In his influential writings, Giorgio Agamben (1998, p. 78) described the refugee camp as the "the absolute, pure, impassable biopolitical space", where control over life and death can be practised. The excessive control and disciplinary power that can be performed in a refugee camp are theoretically derived from the political otherness of refugees entering the body of the nation-state as unwanted, undesirable others (Agier, 2011; Said, 2002). Indeed, the perception of the camp as "other space" is strongly intertwined with the political notions of nationalism, and thus the camp becomes a spatial container for those who have "no right to have rights" (Arendt, 1951).

But other scholars pointed out that camp residents, rather than silently succumbing to the pre-meditated managerial and organisational structuring of daily life in a camp, tend to develop their own counter-strategies to negotiate its spaces and structures. These practices in which refugees engage in the co-production of spaces and subvert models of control and exclusion is what we refer to as refugee agency. Cities and urban areas can play a vital role in facilitating refugees' agency through their heterogeneity, autonomy, and the rich and complex environments they offer (see for example Alshadfan, 2015; Arous, 2013; Fawaz, 2016; Fawaz, Gharbieh, Harb, \& Salamé, 2018). Even refugee camps themselves, where controlling and disciplining are given a wider margin to be exercised, are appropriated and reshaped through refugee agency.

Studying the urbanisation of refugee camps showed how refugees' agency dramatically reshaped the spatiality and physicality, as well as the socio-economy, of camps (Dalal, 2014; Martin, 2015; Misselwitz, 2009; Oesch, 2017; Ramadan, 2013; Sanyal, 2010). For instance, Romola Sanyal (2010) explained how, despite the policing practices of the Lebanese government and the attempt to maintain the temporal nature of the camp, Palestinian refugees managed to urbanise it through the incremental practice of building under the tents and bribing policemen. She points out that "the Palestinian case shows that refugees are active agents in the creation and consolidation of their community, even under conditions of duress" (Sanyal, 2010, p. 885). Therefore, and by recognising the importance of agency in addressing the spatiality of the camp, scholars called for alternative theorisations of the camp to the one offered by Agamben, where control and agency are both equally, and sometimes ambiguously, recognised and addressed (see for instance Isin \& Rygiel, 2007; Katz, 2017; Oesch, 2017).

Amidst the growing interest in refugees' agency and how resistance to oppression can "camouflage" itself and find discursive ways to be expressed (Sanyal, 2010, p. 883), it is often forgotten that control has the same ability to acquire new forms. In the literature on camps, control is either perceived as a result of the sovereign nature of the humanitarian regime (Agier, 2010; Hyndman, 1997; Kagan, 2011) or considered as an intrinsic part of the camp's spatiality. In his lectures at the College du France, Foucault described how camps are planned on a disciplinary basis. He said:

A town is built where previously there was nothing. How is it built? The famous form of the Roman camp is used, which, along with the military institution, was being reutilised at that time as a fundamental instrument of discipline....In the case of towns constructed in the form of the camp, we can say that the town is not thought of on the basis of the larger territory, but on the basis of a smaller, geometrical figure, which is a kind of architectural module, namely the square or rectangle, which is in turn subdivided into other squares or rectangles. (Foucault, 2007, p. 31)

Despite this historical perspective that Foucault offered, interrogations of planning in refugee camps tend to either attempt to improve its "architectural modules" (Kennedy, 2004, 2008), or criticise its standardised, humanitarian and techno-managerial planning (Herz, 2007). We, therefore, argue that the ways in which power, control, and agency are excised through camps' planning remain under explored. This article aims to explore how, just like refugee agency, control also manages to camouflage itself and find alternative ways to be exercised in the context of refugee camps. By focusing on planningits principles, actors, and outcomes, we do not simply aim to re-assert that planning is power and value permeated (Flyvbjerg \& Richardson, 2002; Friedmann, 1993); but that it can be used to exercise control over refugees while claiming the opposite. In particular, we will reveal how the planning of refugee accommodations serves as a tool to encompass concepts such as sustainability and long-term solutions, while simultaneously serving the purpose of camouflaging, aestheticising, and neutralising disciplinary planning and control over refugees. For this, we conceptualise control as monitoring and surveilling, as social and society control in Deleuze's sense (drawing on Foucault's work), but also managing and organising everyday life-over the camp space (Deleuze, 1992; Foucault, 1977). Control is here seen as more than disciplining, as involuntary participation in "mechanisms of control that are equal to the harshest of confinements" (Deleuze, 1992, p. 4), as a "spirit" of the place that renders social systems into numerically measurable entities, thus taking away individuality. Control means then that the controlling regime is only interested in the position of the individual person within a mass-in our case, refugees to be controlled within a camp (cf. Deleuze, 1992). This is on the one hand, while on the other, we perceive agency as the ways in which refugees express individuality, choice, and voice their claims at times when they are least allowed or expected to do so. Thus, agency is not always bluntly expressed-as will be explained in this article, but could be recognised through performativity (cf. Häkli, Pascucci, \& Kallio, 2017), and the subtle negotiations with controlling regimes (Sanyal, 2010). 


\section{Methodology and Approach}

In order to address what we perceive as a global trend in camps' planning, we have chosen two contexts in which the planning of refugee camps did not only play a crucial role in managing "refugee crises"; but have also witnessed transitional shifts in planning where new claims for innovation and development were tested. These two contexts are Jordan, which built several camps for Syrians between 2012 and 2014 and Germany, which has become a destination for many refugees, including Syrians, and has thus produced various new typologies of emergency accommodations especially between 2015 and 2018. In this article, we acknowledge the complex and often hybrid and ambiguous realities of campsspatially and managerially, and their categorisations (see for instance Agier, 2011, pp. 37-59; Mcconnachie, 2016; Oesch, 2017). We are also aware of the political and historical conditions which have made refugee camps "the" appropriate spaces to deal with refugees in the Global South, in opposition to asylum and detention centres used to disrupt refugees' movement to the Global North (Agier, 2011, 2016). While both points will be taken into consideration throughout the analysis, our article aims to find a cross-cutting perspective-in this case, the role of control and agency on camps' planning as a way to challenge these long-established dichotomies and categorisations regarding refugees and camps in different contexts. This approach is not only growing among scholars from different disciplines (see for instance Coddington, 2018; Martin, 2015; Pasquetti, 2015; Sanyal, 2014), but is one that we perceive as a crucial and necessary step towards the development of knowledge in this area of research.

In order to explore how control is being camouflaged in the planning of new camps, the article follows a case study approach. In Jordan, it looks at two concrete examples: Zaatari and Azraq camps built in 2012 and 2014. While in Germany, and due to the ephemeral nature of refugees' management and their spaces, the article looks at different camps encountered between 2016 and 2018. Empirical data in Zaatari and Azraq is obtained through various periods of ethnographic fieldwork carried out by Ayham Dalal during 2014 and 2018. These include participatory observations, walk-alongs, in-depth and semistructured interviews with camp residents and planners during about 30 visits to Zaatari and Azraq camps. This is on the one hand, while on the other, the Berlin case studies started as multiple encounters, experiences and observations noted by the authors between 2014 and 2018. These include the experience of Amer Darweesh going through the asylum process and living in accommodation centres during 2015 and 2016 in parallel to exploratory fieldworks conducted by Anna Steigemann and Ayham Dalal in emergency accommodation centres (Moabit, Lichtenberg, Westend, Tempelhof, Kreuzberg, and Neukölln), with a total of 20 structured interviews with Syrian asylum seekers during 2016, 15 ethnographic and more conversational interviews, supplemented with various walk-alongs and participant observation phases in and around the different accommodations from 2016 until 2018. Empirical data on Tempohomes or "container villages") specifically at Wollenburger Straße and Tempelhof-Columbiadamm) has been obtained by Amer Darweesh, Ayham Dalal, and Philipp Missewlitz during 2018. These include participatory observations, walkalongs, in-depth and semi-structured interviews with camp residents, volunteers working for operators, and site planners at Berliner Real-Estate Management (BIM) and the State Office for Refugees Affairs (LAF). What started as exploratory fieldwork has been fostered in a research project under the title "Architectures of Asylum", which looks at practices of appropriations in refugee camps in Berlin and Jordan. Thus, this article serves as a starting point for the research project, which is part of the Collaborative Research Centre (SFB) 1265 "ReFiguration of Space" in Berlin.

The article applies a comparative cross-case study approach (Gerring, 2011) that is geared towards testing our hypothesis, that the recent planning models of refugee camps are used to camouflage control over refugees while claiming the opposite. In order to capture the interplay between control and agency, we focus on the everyday practices in the camps, and thus, work with a practice-theory approach (Reckwitz, 2003; Schatzki, 1996). With this focus on the practices, the spatial formas a camp or collective accommodation-is conceptualised as a result of the (often conflicting) practices of those who plan, design, organise, manage, and control life in the respective refugee accommodations and their residents. With this methodological approach and the discussed critical analysis of the main recent theoretical concepts and approaches that explain the logic of and innovations in the more technocratic humanitarian regimes' planning of camps and accommodations and the role of refugee agency (or the lack thereof), we focus our comparative study on the concrete changes in the planning of Azraq camp (opened in 2014) as compared to Zaatari camp (2012), as well as on the innovations in the planning of the emergency accommodation Tempelhof airport (2015) to the planning and establishment of Tempohomes (2017) in the following part.

\section{Refugee Camps in Jordan: From Emergency Response to "Sustainable" Settlements}

Jordan is a country that has been long affected by migratory movements. Since its establishment, it has received various waves of refugees, of which the Palestinian remains the most remarkable. This has resulted in more than 10 Palestinian refugee camps scattered around the country (see Al-Husseini, 2010; Chatelard, 2010). Due to these precarious conditions, Jordan did not sign the Geneva Refugee Convention in 1951, and instead, signed a Memorandum of Understanding (MoU) with the United Nations Higher Commissioner for Refugees 
(UNHCR; Al-Kilani, 2014). The unprecedented war on the other side of the borders in 2011 has led thousands of Syrians to slowly seek refuge in Jordan, and especially in the North. Most of the families were able to find silent refuge among families which share a history of kinship transcending colonial borders. Yet the continuous influx of refugees started to affect the underdeveloped structures and services within the Jordanian north. At that time, Syrians, who were rather treated as guests (Achilli, 2015; ILO, 2015), were forced to register as 'refugees' (JRC \& IFRC, 2012). This did not only turn them into humanitarian subjects but meant that they would become recognised and managed under the humanitarian regime. This transition was coupled with a growing frustration between Jordanians living in underdeveloped areas and Syrians, leading the majority of Jordanians to consensus that Syrians should be accommodated in camps (CSS, 2013). Today, however, only $20 \%$ of about 650,000 registered Syrian refugees live in UNHCR camps (including Zaatari, Azraq, the Emirati-Jordanian and King Abdullah Park). These camps are also partly managed by the Jordanian government through the Syrian Refugee Affairs Directorate (SRAD). While accommodating Syrians in camps had its own dynamics, in this article, we will shed the light on how these camps were planned, and how the concepts of control and agency started to shape their spaces and the overall discourse on camp planning.

\subsection{The Planning of Zaatari Camp}

The opening of the Zaatari camp took place under precarious conditions. Relief organisations were given a mere 19 days to prepare a refugee camp in a deserted field near Zaatari village in the north of Jordan (Al-Rai, 2012; UNHCR, 2012a). The initial plan was to accommodate 15,000 persons from temporary accommodation centres near Ramtha as well as from the borders (UNHCR, $2012 b)$. But as numbers rose on a daily basis, the plan soon proved completely insufficient. Refugees were immediately provided with the classical UNHCR tent to shelter families of five members, but other facilities and infrastructure such as shared toilets and kitchens had to wait. The early growth of the camp, therefore, was not conditioned by a master plan, but rather through selforganised squatting practices initiated by refugees themselves. Initially, UNHCR and relief organisations did not exercise control over the resulting settlement arrangements as they were too busy to provide infrastructure (Dalal, 2014; UNHCR, 2014b).

A re-alignment to the standards and guidelines of UNHCR's official Handbook for Emergencies (UNHCR, 2007) only became possible when planning for the camp's extension started. According to Mohammad Jertila, the UNHCR site planner during a personal interview in 2014: "the handbook [became] our bible..... It is, however, our responsibility to respond to challenges as they present themselves on the ground". Consequently, and in contrast to the fluid shelter-space that had evolved organically around the camp's entrance and main street, official planning guidelines were now imposed to lay down a rigid spatial order in the form of a grid and a clear layout of functions which aimed to regularise and control life in the camp. The new camp was divided into districts with clear boundaries, each demarcated by a wide asphalted street. Districts were made up of standardised blocks composed of a matrix of shelters (caravans), arranged in a grid, and surrounded by communal latrines, kitchens, and multi-use spaces. The orderly vision of how districts, services, blocks, accesses, and infrastructures linked together in a master plan (see Figure 1) and stand in stark contrast to the initial camp.

The newly planned part intended to distribute new arrivals in an orderly fashion, and to assist in relocating those living in the older organic part (UNHCR, 2013b, p. 9). Yet, this strategy proved unrealistic to enforce given the highly dynamic situation on the ground. The number of registered residents jumped from 50,000 in January 2013 to 200,000 in May of the same year (Dalal, 2014, p. 57) and, rather than filling up the prescribed gridlines, refugees had begun to squat everywhere: between and inside the planned shelter units (prefabs), in schools, they created markets, making use of all available resources (including communal infrastructure and electricity) to shape camp spaces according to their own needs. Against the logic of an egalitarian grid, refugees moved "their" containers to form small semi-closed clusters in which families and relations gathered, beginning to share resources and establish socio-spatial patterns that are often reminiscent of habitats left behind in Syria. The resulting alternative spatial structure (see Figure 2 ) is a direct consequence of refugee agency mobilizing sociocultural beliefs to find improvised answers to daily needs (Dalal, 2014). Zaatari camp was transformed into one of the "largest urban centres in Jordan" (UNHCR, 2013a). While UNHCR pragmatically conceded its inability to reinforce initial plans and tacitly accepted unplanned "occupations" (cf. Agier, 2011, p. 180), overall, Zaatari became synonymous with planning failure. The issuing of UNHCR's global Policy on Alternative to Camps (2014) can also be read as a negative assessment of "losing control" in camps like Zaatari.

\subsection{The Planning of Azraq Camp}

In order to face an expected "mass displacement" of Syrians (Al-Rai, 2013), in March 2013, the Jordanian government approved the plan to build a new camp called Azraq, located in the empty desert near the international road to Iraq (United Nations [UN], 2014). While this decision was taken in response to the forced migration of refugees arriving in Jordan on a daily basis, there was a gradual decrease in refugee counts in 2013. Therefore, the camp was kept in a "state of readiness" until the decision to officially open it was taken on 30 April 2014 (Jordan Times, 2014; UN, 2014, p. 4). In contrast to the stereotypical case where refugee camps are built and 


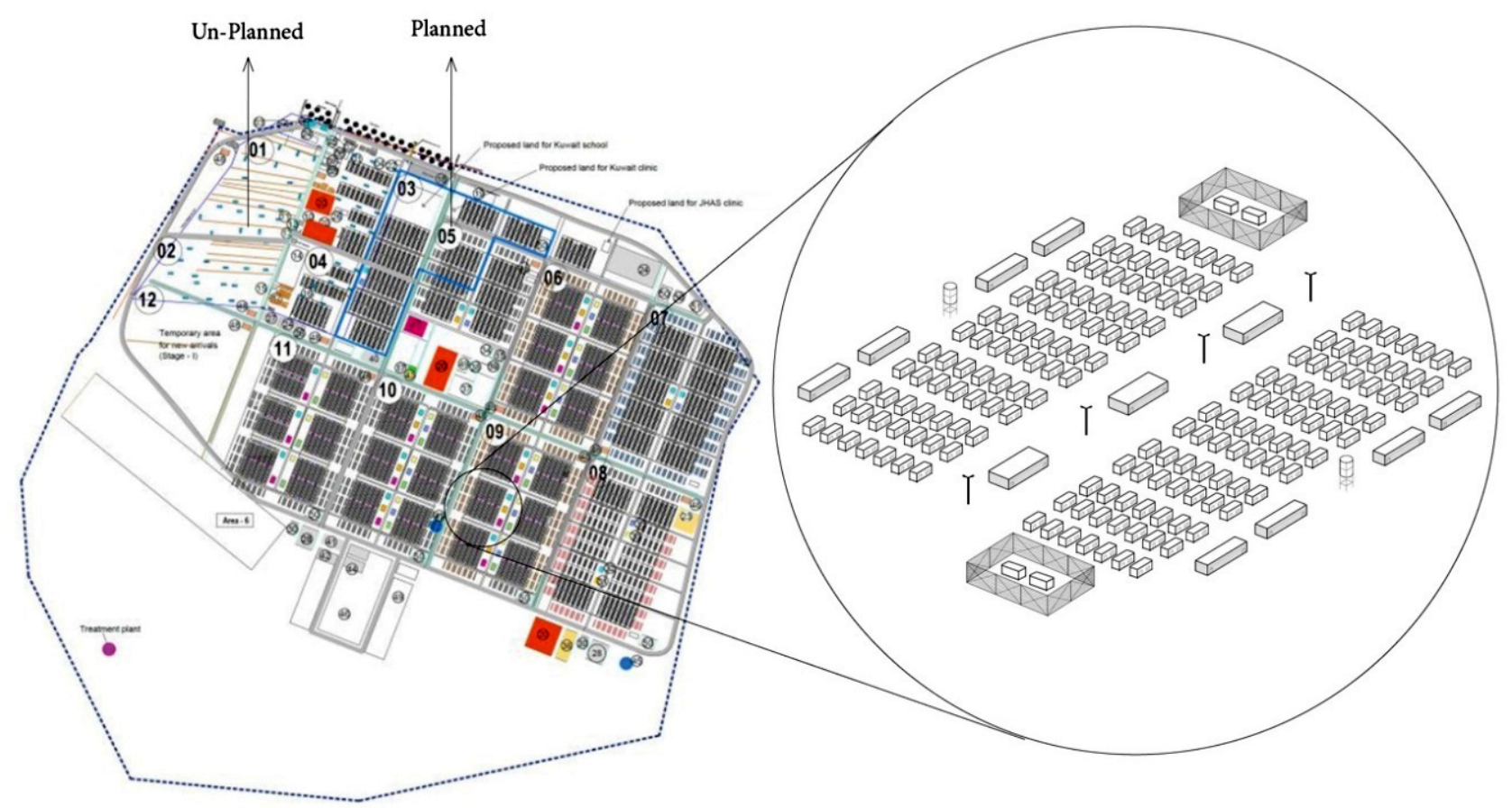

Figure 1. The planning of Zaatari camp and its suggested spatial hierarchy. Source: Dalal based on UNHCR (2014).

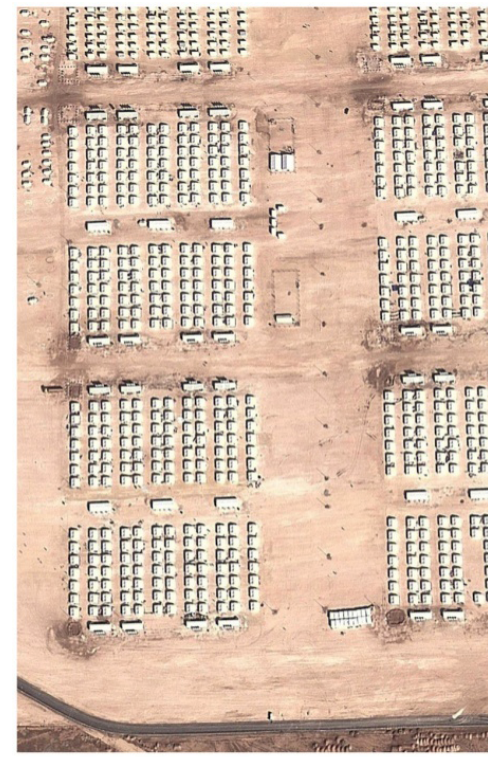

January 2013

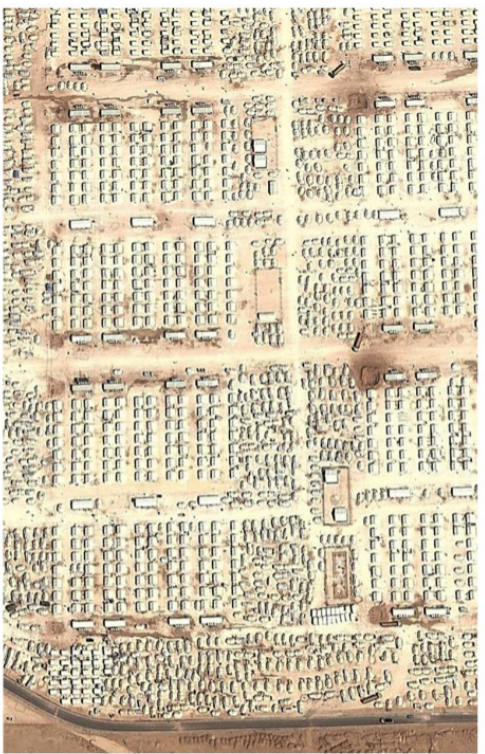

February 2013

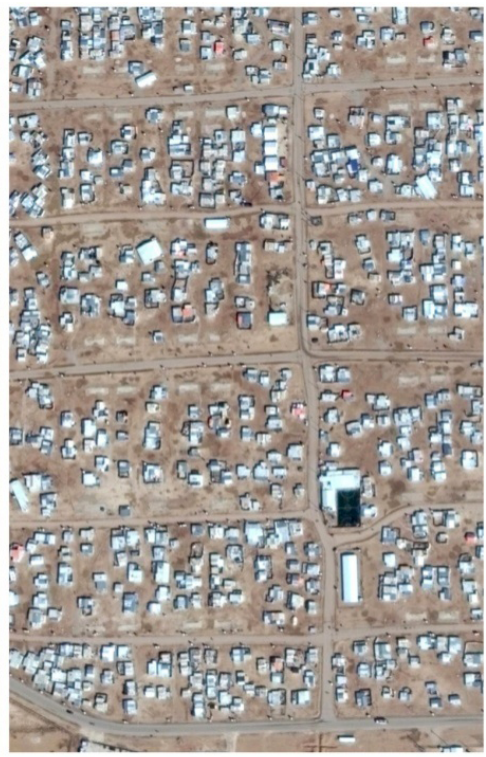

July 2017

Figure 2. The subversion of Zaatari camp's plan through daily urban practices initiated by refugees. Source: Dalal based on Google Earth in 2017.

planned rapidly and in an emergency situation, Azraq camp took around a year of "careful planning and attention" (Jordan Times, 2014). According to the UNHCR representative in Jordan, Azraq camp was perceived as a role model in camp planning and implementation, being described as "one of the best-planned refugee camps in the world" (Jordan Times, 2014).

Azraq camp stretches across a vast area of about $14.7 \mathrm{~km}^{2}$ in which a new strategy of hierarchical spatial differentiation was tested. Camp districts (Zaatari) were now called sub-camps or "villages",-four dedicated to house refugees and one used by management as 'base camp'. The four villages are further subdivided into districts. Each district is divided into plots and each plot is composed of two rows of six identical shelters (see Figure 3). Additionally, the villages are planned as selfcontained and self-sufficient complexes containing their own schools, NGO sites, a community centre, and market space composed of planned rows of market stalls.

UNHCR explicitly and repeatedly emphasised that the planning of Azraq camp was informed by "lessons learnt" from Zaatari camp (cf. UNHCR, 2014a), stress- 


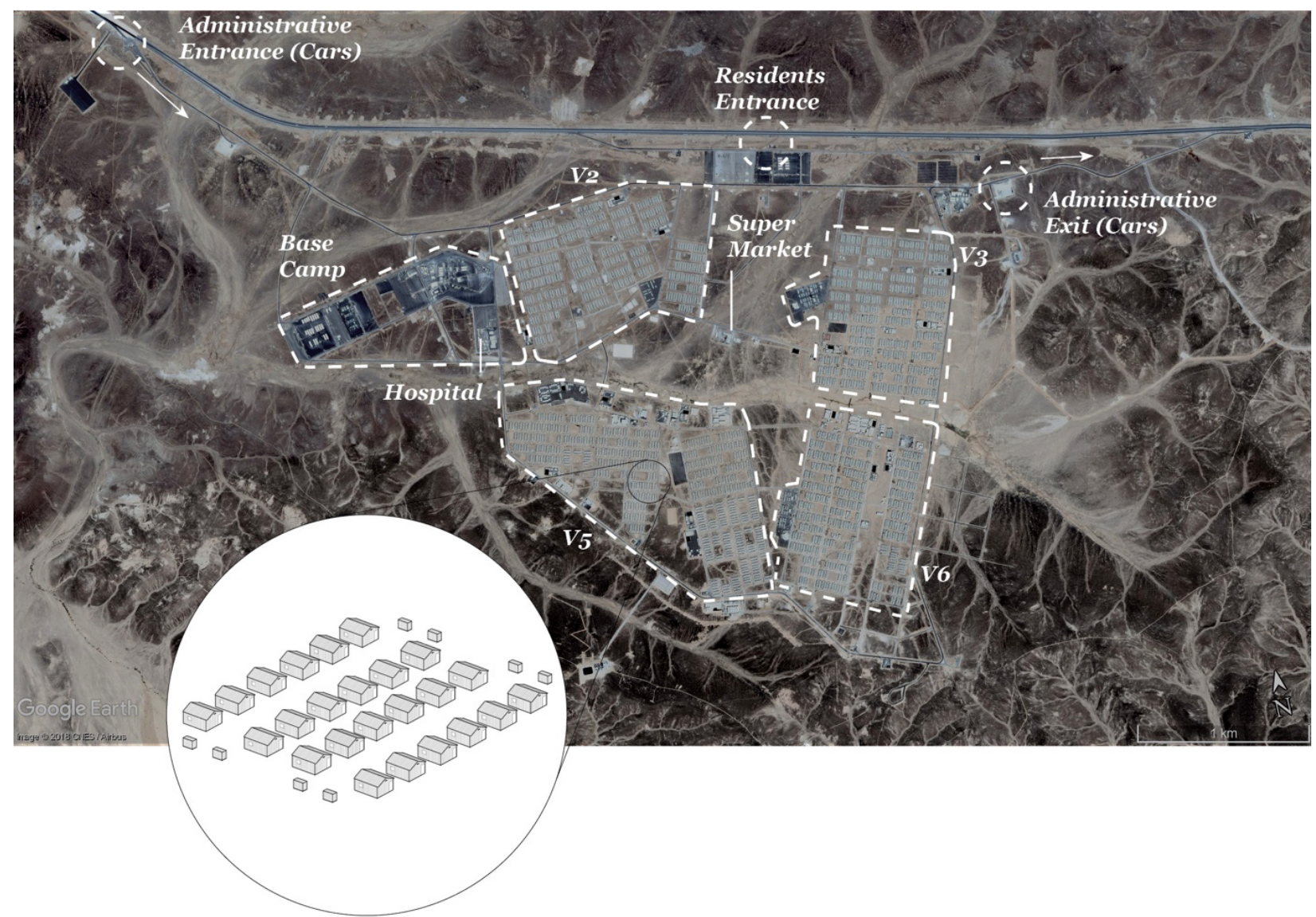

Figure 3. The master plan and shelter typology of Azraq camp. Source: Dalal based on Google Earth, 2017.

ing a recognition for a need for improved shelter design, acknowledging the benefits of decentralising services in self-contained "villages" to improve access or the need for a diversification of functions including supermarkets, market stalls, or designated "local" community centres. Azraq planners engaged in a process that, to some degree, can be likened to "integrated urban planning" which reflects a broad trend in the humanitarian community towards more urban responses to refugee crises (see for instance Crisp, Morris, \& Refstie, 2012). Whilst acknowledging the efforts made by the planning team to rethink the layout, structure, and division of functions deviating from previous norms, we would like to use the dual perspectives of control and refugee agency to evaluate the results.

As stated earlier, defining spatial systems in order to discipline everyday life and service processes has always been a form of managing camps and their populations (cf. Dalal, 2014, 2015; Herz, 2007; Hyndman, 2000; Pasquetti, 2015). The typical grid provided in camps such as Zaatari embodies a humanitarian paradigm attempting to guarantee equal access to services for all camp residents. While it does not foresee or explicitly encourage functional or programmatic diversity, refugee agency mobilises processes of appropriation that can add this diversity to the grid and reshape the camp. While the spatial system of Azraq camps builds urban functions into the plan, it makes refugee-initiated appropriations impossible. The disciplining grid is replaced by a spatial structure of improved control to ensure that the police and the humanitarian organisations are in full charge (Gatter, 2018; Hoffmann, 2017). "Villages" are placed at a considerable distance from each other introducing cordon-sanitaire-like buffer zones, which prevent "groupings", "riots", or "contact" among refugees on a bigger scale. Similarly, external visitors(e.g. researchers) cannot simply access the camp on foot. While attempting to access the camp on foot in 2016, a police officer replied: "No one is allowed to enter the camp without a car....It is impossible to reach the villages by walking from here. You don't imagine how far they are". The basecamp with its key managerial functions is placed at a considerable distance from the "villages" so that it would be difficult to stage demonstrations or protests by refugees, as was frequently the case in Zaatari camp (cf. UNHCR, 2014c). Refugees and their guests enter through a separate access point near the highway and closer to the villages (see Figure 3). All these aspects highlight the dual nature of the plan: to provide a more complex integrated plan to address needs while clearly ensuring improved control over the population of the camp, their movement, and their ability to organise daily life processes. Within the first two years, effective policing made informal spatial practice such as moving or extending shelters, 
which is indicative for refugee agency, almost impossible. As expressed by a young male refugee, who lives in Azraq camp with his wife and daughter:

It is difficult to compare life in Zaatari and Azraq camp....Zaatari is all informal, unlike Azraq. Here everything is well-planned and has been prepared in advanced....You know, we came to the camp, and the shelters were ready to receive us. In Zaatari, people made everything from scratch. But I can tell you that they [police] did not like it! Imagine, the manager of the camp [Azraq] once told us: 'I want to stand between the houses and be able to see the end of the camp!' [Laughing] Such a thing wouldn't be possible in Zaatari camp!

While "effective" planning serves to reduce the space of self-organisation and self-provisioning, margins of informality continue to be negotiable. According to a shelter expert, the presence of empty uninhabited shelters in Azraq camp-waiting to be filled by expected coming refugees-became an opportunity to extend subtle practices of appropriation. Uninhabited shelters would be found dismantled and used to extend shelters through fences or to separate the internal space of the shelter (see Figure 4). During the first two years, strict policing was efficiently practised. Orders to remove additions would be immediately given to refugees once appropriations are spotted on site, and refugees would be warned. Yet, according to the shelter expert, refugees would redo the appropriation once the police were gone. Similar spatial practices of negotiating control have been spotted in Berlin camps as well. The continuous practices of refugees to appropriate the shelters according to their daily needs, however, have led to incremental informalisation of the camp which comes in a strong contrast to its early "neat" image. By that, refugees did not only manage to humanise the camp and gradually create better settings for their domestic lifestyle and needs but also succeeded to subtly negotiate the control initially imposed on them through planning. As a camp official put it in a visit to Azraq in 2018:

Well, usually the police would come and ask people to take this [pointing to a metal fence that had been added around a shelter]...you know, it is not allowed [voice lowered]...but, what to do? People keep changing and adding things around the camp...you know, eventually, they live here. This is a fact. And they are trying to make their lives easier. At the end of the day, our task is not to make their lives more difficult than it already is, but to provide them with protection.

\section{Accommodating Refugees in Berlin: From Reactive Emergency Management to Planned Housing}

Refugee reception in Germany and Berlin is-contrary to Jordan-a highly regulated and complex process administered by state bureaucracies profoundly structuring all aspects of the life of the so-called asylum seekers. During the complex process of applying for asylum, refugees often need to change accommodation beginning with police registration at designated reception or first arrival centres (Ankunftszentrum) in the respective federal country. After registration, a national distribution key called Königssteiner Schlüssel allocates refugees to the federal states (population size and GDP determine the number of allocated refugees) and within the states to different cities and regions. Personal choices, residential preferences, or the existence of other extended family members in the country are not part of this process (Steigemann, 2018; Wendel, 2014, p. 9). Having arrived in their designated location, refugees are then forced to reside in officially recognised emergency accommodations (Notunterkünfte) set up by local municipalities until their "case" has been processed, which can take up to three years. The Federal Office for Migration and Refugees (BAMF) eventually decides if political asylum

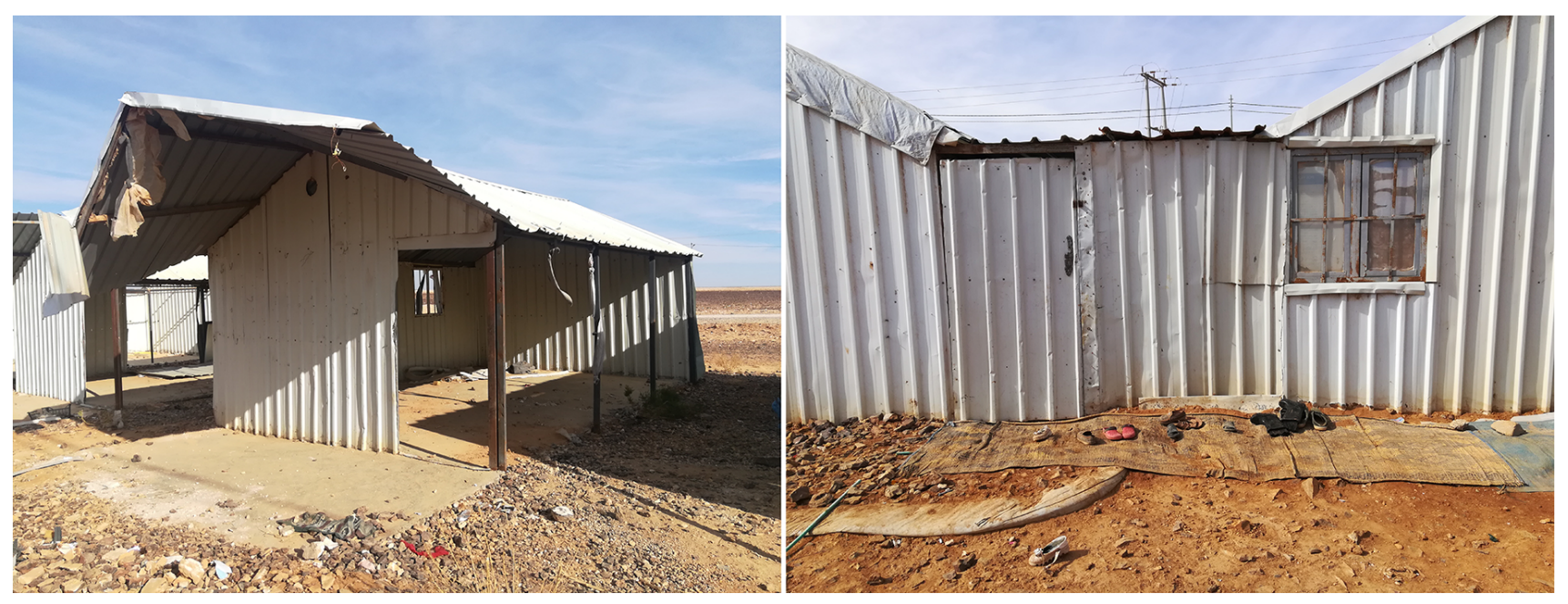

Figure 4. The vandalization of uninhabited shelter units to appropriate inhabited ones and connect them to create additional spaces. Source: Dalal taken in 2018. 
Table 1. From Zaatari to Azraq: Changes in camp governance and physical structure.

\begin{tabular}{lll}
\hline & Zaatari Camp & Azraq Camp \\
\hline $\begin{array}{l}\text { Shifts in camp governance } \\
\text { and management }\end{array}$ & $\begin{array}{l}\text { UNHCR manages the camp with the support } \\
\text { of SRAD }\end{array}$ & SRAD and police are in control \\
\cline { 2 - 3 } & $\begin{array}{l}\text { Emergency situation prevails } \\
\text { Delivery of services (especially shelter) was } \\
\text { not organised }\end{array}$ & $\begin{array}{l}\text { Long-term planning prevails } \\
\text { Delivery of services including shelter } \\
\text { is very organised }\end{array}$ \\
\hline $\begin{array}{ll}\text { The emergence of informal hierarchies as } \\
\text { links between refugees and UNHCR } \\
\text { communication between relief } \\
\text { organisations and refugees }\end{array}$ & $\begin{array}{l}\text { Official community centres have } \\
\text { bigger roles as spaces of }\end{array}$ \\
&
\end{tabular}

\begin{tabular}{|c|c|}
\hline $\begin{array}{l}\text { High reliance on volunteering, multiple } \\
\text { NGOs and relief projects }\end{array}$ & $\begin{array}{l}\text { Limited numbers of NGOs and relief } \\
\text { projects }\end{array}$ \\
\hline $\begin{array}{l}\text { Decentralised services (multiple schools, } \\
\text { hospitals, informal markets and souks, } \\
\text { many youth spaces, etc.) }\end{array}$ & $\begin{array}{l}\text { Centralised services (one main } \\
\text { hospital, one community centre and } \\
\text { market in each village, etc.) }\end{array}$ \\
\hline $\begin{array}{l}\text { Planned initially as an emergency camp } \\
\text { following UNHCR's Handbook of Emergencies }\end{array}$ & $\begin{array}{l}\text { Planned as a "city" using external } \\
\text { urban planning and design expertise }\end{array}$ \\
\hline $\begin{array}{l}\text { Centralised layout following block standards } \\
\text { with functional zoning }\end{array}$ & $\begin{array}{l}\text { Very clear spatial hierarchy: } \\
\text { Plot }<\text { Block }<\text { District }<\text { Village }<\text { Camp }\end{array}$ \\
\hline $\begin{array}{l}\text { The planning process was hectic as it } \\
\text { happened while people were settling }\end{array}$ & $\begin{array}{l}\text { The camp took about a year of } \\
\text { careful planning }\end{array}$ \\
\hline $\begin{array}{l}\text { Perceived as "chaotic" and "informal" due } \\
\text { to a high degree of refugee initiated } \\
\text { appropriations and changes }\end{array}$ & Perceived as "ordered" and "formal" \\
\hline Most shelters are movable & All shelters are fixed \\
\hline Different types of shelter units & One type of standardised shelter \\
\hline $\begin{array}{l}\text { Refugees are difficult to allocate within the } \\
\text { camp until recently (when the address } \\
\text { system was installed in 2015) }\end{array}$ & $\begin{array}{l}\text { Refugees are easy to allocate using } \\
\text { addresses }\end{array}$ \\
\hline Zaatari camp is considered as a "bad" model & $\begin{array}{l}\text { Azraq camp is considered as "the } \\
\text { best" model }\end{array}$ \\
\hline
\end{tabular}

Changes in spatial structure and physical characteristics (which can be extended to permanent residency provided the fulfilment of strict conditions) or humanitarian asylum is granted, which limits residency rights to one year and reduces rights to apply for family reunions or employment possibilities (cf. Tometten, 2018). Only after the asylum status is clarified, do refugees have the right to choose their own accommodations but, given limited financial means and high rental prices, often continue to reside in designated state provisions.

This article will focus on the accommodation crisis triggered by the arrival of nearly one million refugees following the brief period of "open-door policy" in Germany and the subsequent effort by municipalities to find new accommodation solutions within the given, highly structured and bureaucratised refugee administration system outlined above and the equally bureaucratised general planning system. Initially, unprepared for the high number of arriving refugees, many cities had resorted to improvised emergency measures including tents, organised squatting of factory halls or school gymnasia, which Rene Kreichauf (2018) referred to as "campization"-a tendency towards accommodating refugees in Europe in spaces that resonate with refugee camps in the Global South. Also in Berlin, which in 2014-2015 received an estimated 80,000 refugees, the emergency accommodation capacity had to be radically extended. Makeshift solutions included the reuse of vacant structures, often publicly owned, such as the empty hangars of the former inner-city airport Tempelhof. Here, several of the vast industrial halls were transformed through the introduction of a grid of temporary walls forming small $12 \mathrm{~m}^{2}$ cubicles for up to 12 persons sleeping in bunk beds - up to 800 persons in total per hangar, approximately 2500 in total. Instead of doors, loose curtains separated cubicles from access corridors reducing any possibility of privacy further. In addition, the cells were not roofed, which 
led to residents complaining about noise and light obstructions (see Figure 5). To provide order and security in these harsh conditions strict rules were put in place that regulated all daily routines, from the regulation of lights (switch-off times in the evening at 22 hours) to catered meals and strict access control. Under such harsh conditions, the scope for refugee-initiated appropriations is very limited. Nevertheless, left-over spaces or widercorridor sections became hang-out spaces for groups of men, others for women with self-initiated sofa arrangements and wall graffiti. One refugee interviewed in July 2016 had managed to open a small hair-dressing service using a recycled chair and shelves he had obtained through one of the guards: "We are not used to being dependent....If I did not manage to work here I would have gone back to Syria long ago". Yet, overall, self-initiated appropriations remained scarce and only possible through leniency of guards and local management. Most refugees reported on health and safety checks insisting on immediate removal of any violations.

Following intense criticism of the inhumane and overcrowded conditions at the Tempelhof hangars and other equivalent settings, as well as several scandals involving corruption and mismanagement at Berlin's State Office for Health and Social Affairs (LaGeSo), the city was forced to rethink both administrative management and develop new accommodation strategies for refugees. This involved, for the first time, not only state actors but also professional planners and architects, and was coordinated from September 2014 onwards by a newly formed task force including experienced personnel from the city's planning administration. A first measure in- cluded the installation of six "container villages" (LaGeSoDörfer) planned in 2014 and opened in early 2015, composed of stacked containers placed in mostly peripheral locations in the city. The Task Force had managed to bypass complicated and delaying planning laws by designating the structures as temporary. As collective accommodation centres (Gemeinschaftsunterkünfte), the "container villages" were supposed to house refugees waiting for their asylum application process and, like all other state-funded centres, provided intense and continuous supervision and monitoring. While the task force was initially briefed to design housing for 2,000 refugees, in 2016, it became clear that at least nine times more refugees needed to be accommodated. With a newly formed LAF in charge (Lübbe, 2017; RBB|24, 2018) new ideas for how refugee camps should be managed and planned started to emerge. Rather than temporary solutions, the administration conceived the idea of Modular Accommodation for Refugees (ModulareUnterkünftefürFlüchtlinge-MUFs), a cheap yet long-term, durable, standardised building type which would allow for re-use as affordable housing for homeless persons, or student housing in the medium and long-term. This strategy reflected a shift towards considering refugee accommodation as part of the general housing crisis in the city. The support of local districts and the general public, it was hoped, would be greater if investments could be seen to address the shortage of affordable homes for other constituents too.

Planning for a more durable solution also meant following building regulations and completion was expected to take at least 2-3 years. A new German building code (BauGD §246-Flüchtlingsunterbringungsmassnah-

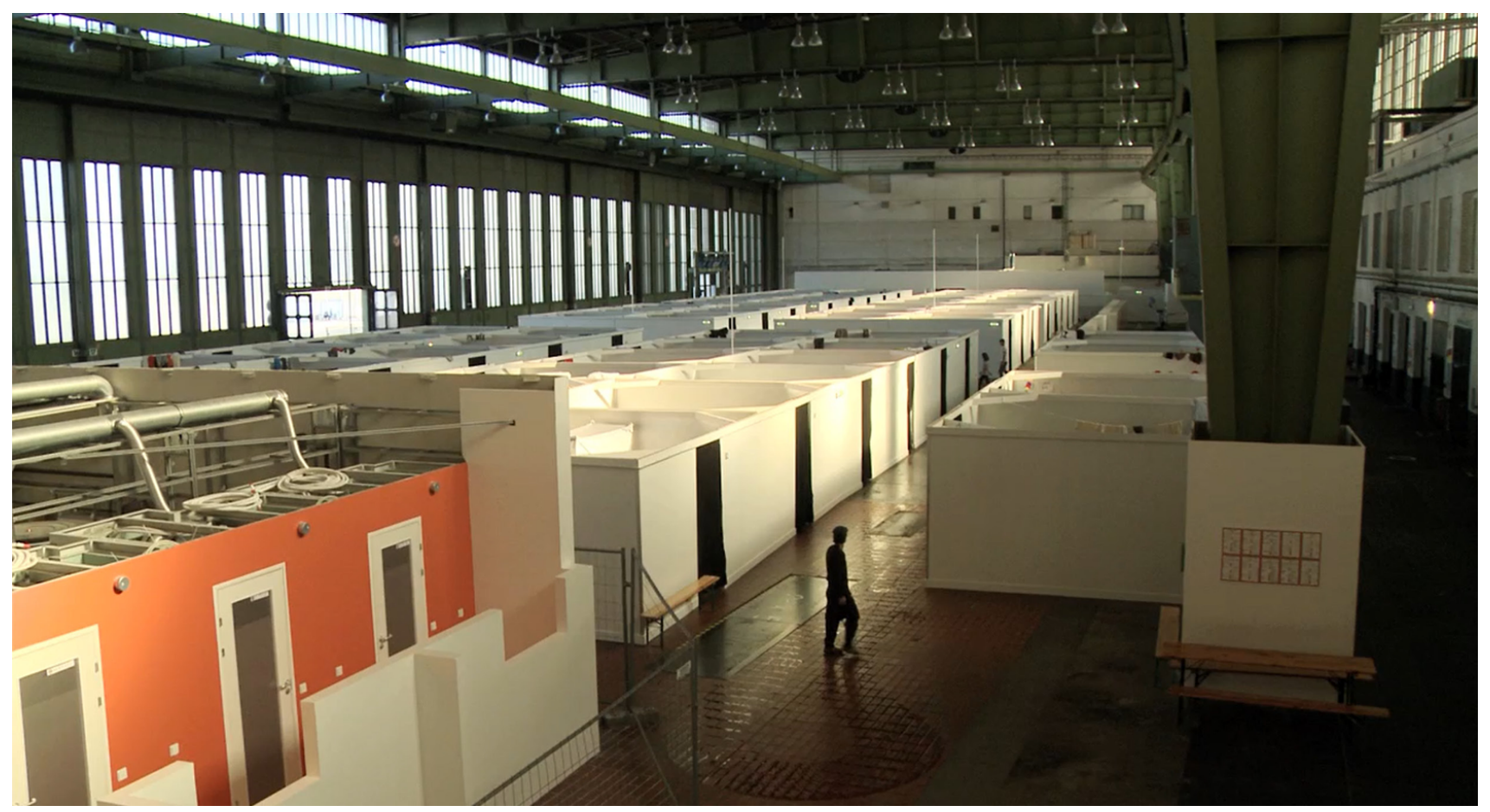

Figure 5. A perspective into the planned emergency shelter at the former Tempelhof airport in Berlin in 2016. Source: Misselwitz, taken in 2016. 
mengesetz) designed specifically to speed up the process of accommodating refugees, limited for submissions until December 2019, opened a window for another interim solution. Planning parameters included standardisation, the speed of construction, efficiency in maintenance, and alignment with complex fire safety rules, and led to a prefabricated, single-storey container-based solution called Tempohomes (see Figure 6). For realisation, the LAF contracted another governmental authority known as the BIM, which then, subcontracted architectural offices to provide designs and plans matching tightly prescribed LAF standards. Solutions could be scaled to match the carrying capacity of local sites, and resident numbers therefore vary between a150 and 1000 . With new Federal funding opportunities, LAF standards were later revised to also include specific requirements for social meeting spaces, playgrounds, and leisure facilities. Containers were improved through the introduction of a small porch-like element at the entrance. Tempohomes now included a much broader spectrum of functions and facilities-even areas for planting or socio-cultural projects-resembling, albeit on a much smaller scale, the shift towards urban planning described at Azraq camp in Jordan. This shift can be considered a direct "learning" from earlier omissions and experimentation following persistence and pressure from external NGOs and refugee groups.
The shift from techno-managerial emergency accommodations to "designed" Tempohome solutions also determined the re-organisation of the former Tempelhof airport. Following public pressure, in late 2017, most of the hangars were closed and refugees shifted towards a newly erected Tempohome "village" for over 1000 refugees, located immediately outside of the building on the airfield itself. Following revised LAF standards, the new site included a whole range of central and decentralised public spaces. Carefully designed, extensive wooden terraces between containers include seating arrangements; pergolas providing shade and rain protection; and numerous sports and social facilities (see Figure 6).

Seen through a perspective of control and refugee agency, such new and "good-looking" Tempohomes, however, appear rather ambivalent. The overall planning focus on open public space and "village" rhetoric camouflages persisting control and monitoring from security staff and camp management. Refugees frequently expressed their frustration with control exercised over their private spaces and their coping strategies. A female Tempohome resident explained:

I don't like this picture in my room. Imagine that we are not allowed to change anything here without the permission of the social worker! Therefore, I cover it

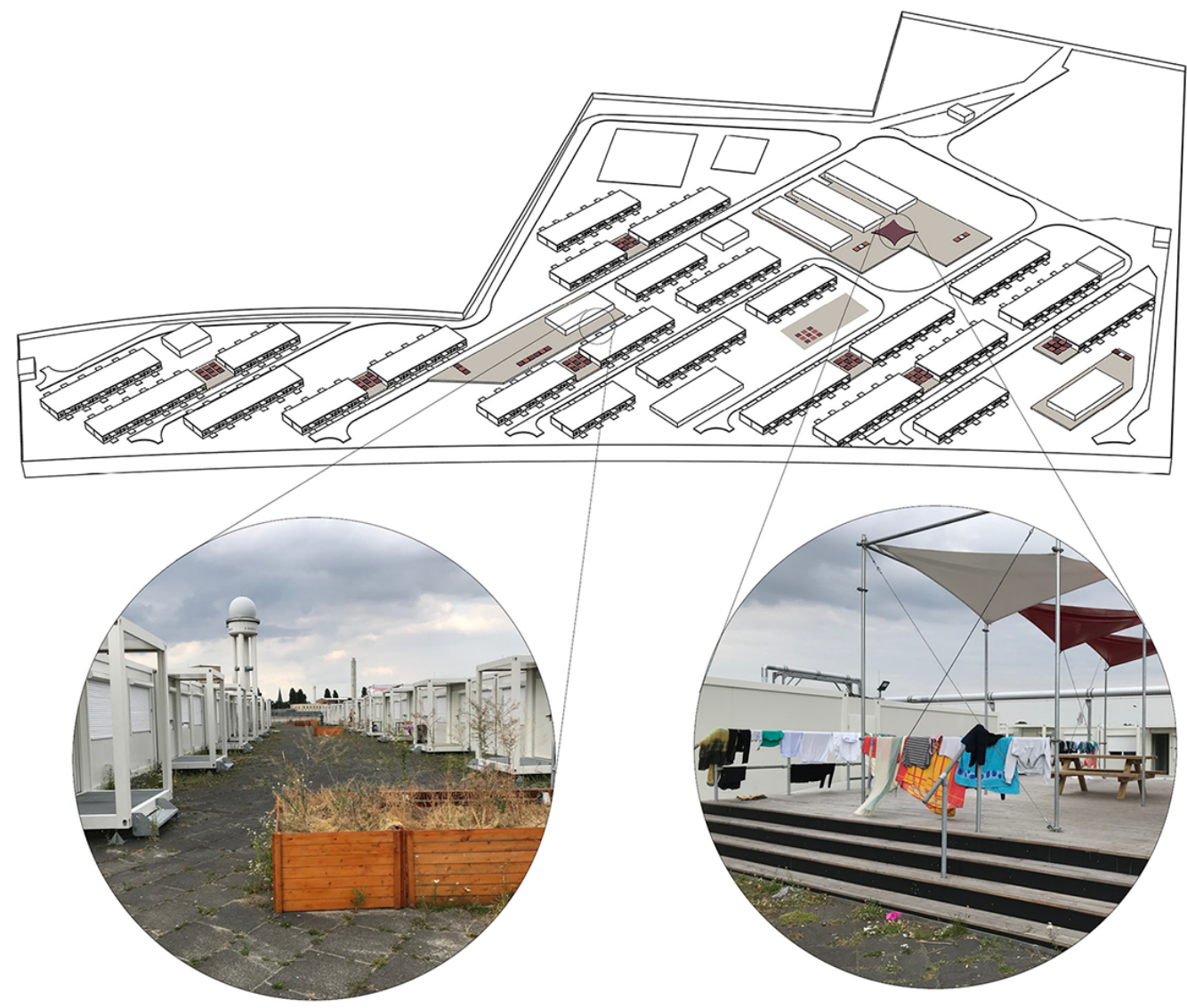

Figure 6. The Tempohome at Columbia-Damm (Tempelhof) showing designed social spaces and how they are appropriated or left unused. Source: Darweesh, Dalal and Misselwitz in 2018. 
with a plastic sheet because I don't like to see it...and when I know that they [social workers] are coming to visit, I remove the sheets beforehand.

Another male interviewee explained:

Security guards here always ask us to bring the furniture inside, but where? They are only doing what they are asked to do. There is no place for this table inside. When we know that someone from LAF will come to visit the camp, we take our furniture inside and then we take it out after they leave. Even the carpet, despite the cold, is forbidden to be placed on the floor under the pretext of fire protection. It is our habit to sit on the ground with the family to eat, for example. We can't do everything they say, life on the ground is different from what they think and plan.

At another Tempohome in Wollenberger Straße, one of the residents wanted to plant a small garden outside his container which reminded him of his house and garden in Syria. However, shortly after, he was requested to detach it from the containers and move it to the garden, because he was told that it would block the emergency access through the window (see Figure 7). Others reported the forced removal of added curtains on porches or informal seating arrangements. Designed public spaces or wooden decks remain noticeably empty and underused (with the exception of sports facilities for kids) or, in more decentralised locations, the Tempohome Columbia-Damm for instance, spaces designed for social activities are appropriated for drying laundry (see Figure 6). Access for the public tends to be carefully controlled and, in most Tempohomes and MUFs, is granted only based on prior written application and approval. While these could be justified as 'security measures', the control practised over refugee accommodations reduces self-determined spaces in which agency and self-expression could unfold.
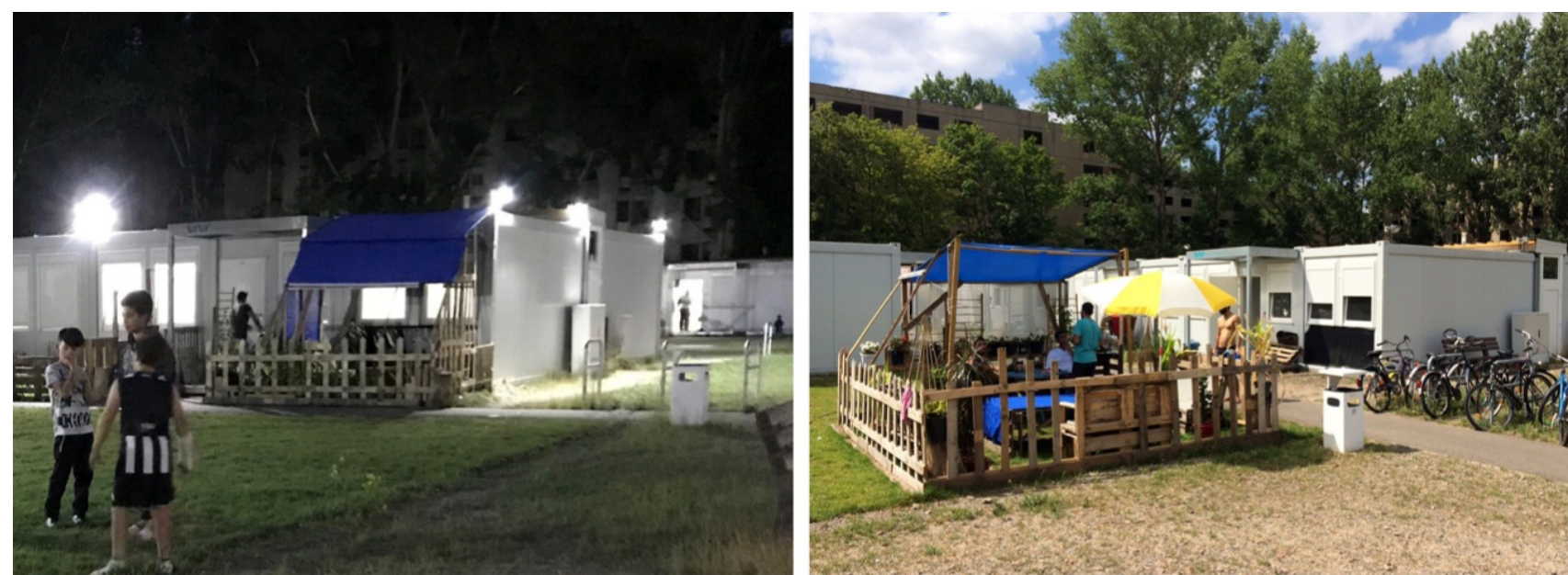

Figure 7. The controlling of appropriated spaces at the Tempohome in Wollenberger Straße. Source: Darweesh and Misselwitz, taken in 2018.
The persisting control and reduced refugee agency extend to social mixing approaches from LAF and local management teams as well. When asked whether social organisation and the formation of social hierarchies amongst Tempohome residents are encouraged, a local manager replies:

We do not want refugees to group within their own language and cultural groups. We also do not want to privilege certain individuals over others. Refugees have to learn to live in Germany, according to our values where everybody is the same, where people from many nationalities and religious groups live peacefully side-by-side-not segregated. If they don't learn it here, when should they learn it?

While fostering "integration" is the declared paradigm of LAF, which has devised the concept of an integration ladder from dependence towards higher levels of autonomy and self-organisation, the statement reveals the degree to which "integration" is understood as assimilation paradigm when applied to practical camp management. Managing camp life is seen as an educative task supported by appropriate rules and regulations, preparing successful asylum seekers for life in the "proper" city. The architectural design of Tempohomes is its physical and material equivalent: Here, the architecture appears to serve as a means to an end, describing a landscape of "proper" living, which prepares refugees for assimilation into the German city.

\section{Conclusions: Comparing Planning Innovations and Outcomes across Germany and Jordan}

By exploring the recent transformations of refugee camps planning and spatiality using examples in Jordan and Germany, we identified comparable trends-a shift towards applying urban planning approaches to camps which, as a result, appear to be more city-like urban 
Table 2. Managerial and physical characteristics of refugee accommodations in Berlin.

\begin{tabular}{|c|c|c|c|}
\hline & \multicolumn{2}{|l|}{ Emergency Accommodation } & \multirow{2}{*}{$\begin{array}{l}\text { Long-Term Accommodation } \\
\text { GU2 }\end{array}$} \\
\hline & $\begin{array}{l}\text { Reception Facilities (EAE; } \\
\text { e.g. Tempelhof Hangar) }\end{array}$ & Tempohomes (GU1) & \\
\hline \multirow[t]{4}{*}{$\begin{array}{l}\text { Shifts in camp governance } \\
\text { and management }\end{array}$} & $\begin{array}{l}\text { Managed by an } \\
\text { operator (NGO) } \\
\text { appointed by LaGeSo }\end{array}$ & $\begin{array}{l}\text { Managed by an } \\
\text { operator (NGO) } \\
\text { appointed by LAF }\end{array}$ & $\begin{array}{l}\text { Managed by an operator (NGO) } \\
\text { appointed by LAF }\end{array}$ \\
\hline & $\begin{array}{l}\text { Provision of } \\
\text { emergency assistance } \\
\text { and monitoring }\end{array}$ & $\begin{array}{l}\text { Provision of services such } \\
\text { as social work, translation, } \\
\text { child care, etc. }\end{array}$ & Fewer services are provided \\
\hline & Guarded by security & Guarded by security & Guarded by security \\
\hline & $\begin{array}{l}\text { Stay no more than } \\
\text { six weeks }\end{array}$ & No more than 3 months & Stay until phased out \\
\hline \multirow[t]{5}{*}{$\begin{array}{l}\text { Changes in spatial structure } \\
\text { and physical characteristics }\end{array}$} & $\begin{array}{l}\text { Refurbishing of } \\
\text { existing buildings } \\
\text { such as hospitals, } \\
\text { schools, sports halls, } \\
\text { etc. }\end{array}$ & $\begin{array}{l}\text { Refurbishing of existing } \\
\text { buildings } \\
\text { and/or }\end{array}$ & $\begin{array}{l}\text { Newly planned and designed } \\
\text { buildings } \\
\text { and/or }\end{array}$ \\
\hline & & $\begin{array}{l}\text { Planning and designing } \\
\text { small settlements } \\
\text { using containers } \\
\text { (Tempohomes) }\end{array}$ & $\begin{array}{l}\text { Planning and designing small } \\
\text { settlements using containers } \\
\text { (Tempohomes) }\end{array}$ \\
\hline & Improvised shelter & Planned shelter & Planned shelter \\
\hline & $\begin{array}{l}\text { Up to } 12 \text { persons in } \\
\text { one } 25 \text { sqm cubicle } \\
\text { (Tempelhof) }\end{array}$ & $\begin{array}{l}2 \text { persons in one } \\
\text { container space }\end{array}$ & 1 person per room \\
\hline & $\begin{array}{l}\text { Ad-hoc utilisation of } \\
\text { available space }\end{array}$ & $\begin{array}{l}\text { Tempohomes planned as } \\
\text { settlements or small camps }\end{array}$ & MUF designed as housing \\
\hline
\end{tabular}

habitats. In both instances, this has been the result of processes of learning from previous failures; often combined with external pressure and critiques. In the case of Jordan, this includes lessons that were drawn from informal urbanisation processes at Zaatari and then applied to Azraq, including a recognition of a more decentralised arrangement with sub-districts ("villages") and more complex functions needed to make the setting "sustainable". In the Berlin case, learning from the failures and critiques of emergency accommodation arrangements in the early years of the current "refugee crisis", as exemplified in the Tempelhof hangars, led to the revision of standards and the matter planning of Tempohomes-designed container arrangements as aesthetic urban public spaces. Both cases discussed in this article seem to reveal genuine attempts to apply principles of urban planning and architectural design to improve previous approaches to technocratic emergency shelter provision. In both cases, some of the learning was directly responding to the rationalisation of previous planning failures and needs that became apparent through the appropriation of camp residents themselves. Generally, the more urban designoriented approaches reflect a growing involvement of ur- ban professionals in humanitarian contexts, which can be equally observed in other contexts.

However, when observed from the perspectives of control and refugee agency-both key concepts developed in critical refugee studies-the planning outcomes are much more ambivalent. While a certain "recognition" of refugees self-determination played a role in formulating and explaining new design approaches, the results reveal a tendency towards aestheticisation and formalisation rather than increasing autonomy and spaces of selfprovisioning, which are core to the concept of refugee agency. As Tables 1 and 2 show, by summarising the policy-initiated shifts in management and physical characteristics, in the well-designed camp environment, the loopholes for self-provisioning and appropriation are actually shrinking.

In Jordan, where enforcement of humanitarian guidelines and norms was-as the example of Zaatari showsinitially weak and informal appropriations flourished, the well-designed camp of Azraq seems to have decreased the scope of appropriations in exchange for a spatial arrangement fostering increased control. In Germany, where refugee accommodations had always followed 
much stricter and tightly enforced norms and standards, better housing and access to designed open spaces and outdoor facilities also seemed to have the contradictory effect of solidifying and further stabilising control. New and clean-looking materiality in Azraq camp and Berlin's Tempohomes, despite the increased sense of privacy of containers and modules and, in the Jordan case, more hybrid housing forms, become part of a controlling, disciplining educative landscape, personified in the constant presence of security guards, fences, social workers, and health and safety patrols. The shift led from the stereotypical, technocratic shelter and layout types towards camps that look like houses and are referred to as "villages" in both Jordan and Berlin. While this shift is perceived from the outside as "positive", our article tried to emphasise the need to take these shifts into deeper consideration, as ways in which the refugee camp-as Agamben warned us, manages to veil itself in ways that we need to recognise.

Hence, while the inclusion of design and planning professionals in the improvement of refugee camps is commendable, the results can threaten to camouflage and soften the disciplinary powers embedded within the framework offered by the refugee camp through planning. Looking deeper into the spatial practices and agency of refugees in camps allows for a critique of their planning. Furthermore, it should also inform new guiding principles for less expert-driven, controlling and more participative, cooperative, experimental, and open-ended planning that appreciates and includes the spatial knowledge and practices of refugees as the ultimate users and residents of the designed place. This could enable less finished and maybe less aesthetically pleasing, yet more genuinely inclusive attempts to provide more adequate and dignified spaces for refugee protection.

\section{Acknowledgements}

We wish to thank the editors and the anonymous referees for their engaged and helpful comments and suggestions that helped to improve the focus of this article. We are also grateful to the Deutsche Forschungsgemeinschaft (DFG, German Research Foundation)Project number 290045248-SFB 1265, for their financial support, and for offering us an inspiring research environment at the Collaborative Research Centre "Re-Figurations of Space".

\section{Conflict of Interests}

The authors declare no conflict of interests.

\section{References}

Achilli, L. (2015). Syrian refugees in Jordan: A reality check (Policy Briefs 2015/2). Florence: Migration Policy Center.
Agamben, G. (1998). Homo Sacer: Sovereign power and bare life. Stanford: Stanford University Press.

Agier, M. (2010). Humanity as an identity and its political effects (a note on camps and humanitarian government). Humanity: An International Journal of Human Rights, Humanitarianism, and Development, 1(1), 29-45.

Agier, M. (2011). Managing the undesirables: Refugee camps and humanitarian government. Cambridge: Polity Press.

Agier, M. (2016). Afterword: What contemporary camps tell us about the world to come. Humanity: An International Journal of Human Rights, Humanitarianism, and Development, 7(3), 459-468.

Al-Husseini, J. (2010). The management of the Palestinian refugee camps in Jordan between logics of integration and exclusion. SSRN Electronic Journal, 2010(January). Advanced online publication. https://doi.org/10.2139/ssrn.2166837

Al-Kilani, S. (2014). A duty and a burden on Jordan. Forced Migration Review, 47, 30-31.

Al-Rai. (2012). السوريين. اللاجئين لإيواء الزعتري مخيم افتناح Retrieved from www.alrai.com/article/530134.html

Al-Rai. (2013). اللاجئين لاستقبال مركز السرحان رباع مخيم/articled Retrieved from alrai.com/article/ 568948.html

Alshadfan, R. (2015). The Trends of housing transformation in border cities hosting refugees: The case of Mafraq City (Unpublished Master's dissertation). Faculty of Architecture, Stuttgart University, and Ain Shams University, Stuttgart and Cairo.

Arendt, H. (1951). The origins of totalitarianism. New York, NY: Harcourt, Brace \& World.

Arous, R. (2013). Refugee setting and urban form and governance: The predicament of Syrian refugees in navigating Cairo's urban spaces and the complexities of governance in turbulent times (Unpublished Master's dissertation). Faculty of Architecture, Stuttgart University, and Ain Shams University, Stuttgart and Cairo.

Chatelard, G. (2010). Jordan: A refugee haven. Confremo. Retrieved from hal-confremo.archives-ouvertes.fr/ halshs-00514403

Coddington, K. (2018). Landscapes of refugee protection. Transactions of the Institute of British Geographers, 43(3), 326-340.

Crisp, J., Morris, T., \& Refstie, H. (2012). Displacement in urban areas: New challenges, new partnerships. Disasters, 36(s1).

CSS. (2013). Public opinion survey: Some current issues in Jordan 2013. Amman: Center of Strategic Studies.

Dalal, A. (2014). Camp cities between planning and practice: Mapping the urbanisation of Zaatari camp (Unpublished Master's dissertation). Faculty of Architecture, Stuttgart University, and Ain Shams University, Stuttgart and Cairo.

Dalal, A. في الحوكمة إشكاليات السياسة: و الفراغ بين .(2015) في الأردن شمال الزعتري مخيم 
itics: Problematizing governance in Zaatari camp in Northern Jordan]. Idafat: Arab Journal of Sociology, 31, 118-133.

Deleuze, G. (1992). Postscript on the societies of control. October, 59(Winter), 3-7.

Fawaz, M. (2016). Planning and the refugee crisis: Informality as a framework of analysis and reflection. Planning Theory, 16(1), 1-17.

Fawaz, M., Gharbieh, A., Harb, M., \& Salamé, D. (Eds.). (2018). Refugees as city-makers. Beirut: Issam Faris Institute, American University of Beirut.

Flyvbjerg, B., \& Richardson, T. (2002). Planning and Foucault: In search of the dark side of planning theory. In P. Allmendinger \& M. Tewdwr-Jones (Eds.), Planning futures: New directions for planning theory (pp. 44-62). London and New York: Routledge.

Foucault, M. (1977). Discipline and punish (A. Sheridan, Trans.). New York, NY: Vintage.

Foucault, M. (2007). Security, territory, population: Lectures at the College de France, 1977-78. (M. Senellart, F. Ewald, A. Fontant, \& A. Davidson, Eds.). Basingstoke: Palgrave Macmillan.

Friedmann, J. (1993). Toward a non-Euclidian mode of planning. Journal of the American Planning Association, 59(4), 482-485.

Gatter, M. (2018). Rethinking the lessons from Za'atari refugee camp. Forced Migration Review, 57, 22-24.

Gerring, J. (2009). The case study: What it is and what it does. In C. Boix \& S. C. Stokes (Eds.), The Oxford Handbook of comparative politics. Retrieved from www.oxfordhandbooks.com/view/10.1093/oxfordhb /9780199566020.001.0001/oxfordhb-97801995660 20-e-4

Häkli, J., Pascucci, E., \& Kallio, K. P. (2017). Becoming refugee in Cairo: The political in performativity. International Political Sociology, 11(2), 185-202.

Herz, M. (2007). Refugee camps in Chad: Planning strategies and the architect's involvement in the humanitarian dilemma (Research Paper no. 147). Geneva: UNHCR.

Hoffmann, S. (2017). Humanitarian security in Jordan's Azraq Camp. Security Dialogue, 48(2), 97-112.

Hyndman, J. (1997). Refugee self-management and the question of governance refugee camps Kenya. Refuge, 16(2), 16-22.

Hyndman, J. (2000). Managing displacement: Refugees and the politics of humanitarianism. Minneapolis, MN: University of Minnesota Press.

ILO. (2015). Access to work for Syrian Refugees in Jordan: A discussion paper on labour and refugee laws and policies. Amman: International Labour Organization.

Isin, E., \& Rygiel, K. (2007). Abject spaces: Frontiers, zones, camps. In E. Dauphinee \& C. Masters (Eds.), Logics of biopower and the war on terror ( $\mathrm{pp}$. 181-203). Basingstoke: Palgrave Macmillan.

Jordan Times. (2014). Azraq refugee camp officially opened. Jordan Times. Retrieved from www.jordan times.com/news/local/azraq-refugee-camp-officially -opened

JRC, \& IFRC. (2012). Syrian refugees living in the community in Jordan (Assessment Report). Amman: Jordan Red Cross and International Federation of Red Cross Societies.

Kagan, M. (2011). "We live in a country of UNHCR": The UN surrogate state and refugee policy in the Middle East (Paper 20). Geneva: UNHCR.

Katz, I. (2017). Between bare life and everyday life: Spatialising Europe's migrant camps. Architecture_MPS, 12(2), 1-20.

Kennedy, J. (2004). Towards a rationalisation of the construction of refugee camps (Unpublished Master's dissertation). Faculty of Architecture, KU Leuven, Leuven.

Kennedy, J. (2008). Structures for the displaced: Service and identity in refugee settlements (Unpublished Doctoral dissertation). Faculty of Architecture, TU Delft, Delft.

Kreichauf, R. (2018). From forced migration to forced arrival: The campization of refugee accommodation in European cities. Comparative Migration Studies, 6(7), $1-22$.

Lübbe, S. (2017). Hilfsbedürftige im Amt. Zeit Online. Retrieved from www.zeit.de/gesellschaft/zeitgesche hen/2017-11/laf-fluechtlinge-behoerde-problememitarbeiter

Martin, D. (2015). From spaces of exception to "campscapes": Palestinian refugee camps and informal settlements in Beirut. Political Geography, 44, 9-18. https://doi.org/10.1016/j.polgeo.2014.08.001

Mcconnachie, K. (2016). Camps of containment: A genealogy of the refugee camp. An International Journal of Human Rights, Humanitarianism, and Development, 7(3), 397-412.

Misselwitz, P. (2009). Rehabilitating camp cities: Community driven planning for urbanised refugee camps (Unpublished Doctoral dissertation). Faculty of Architecture, Stuttgart Univeristy, Stuttgart.

Oesch, L. (2017). The refugee camp as a space of multiple ambiguities and subjectivities. Political Geography, 60, 110-120.

Pasquetti, S. (2015). Negotiating control. City, 19(5), 702-713.

Ramadan, A. (2013). Spatialising the refugee camp. Transactions of the Institute of British Geographers, 38(1), 65-77.

RBB |24. (2018). Nach weniger als zwei Jahren Chefin des Berliner Flüchtlingsamts geht. RBB/24. Retrieved from www.rbb24.de/politik/beitrag/2018/04/lan desamt-fuer-fluechtlingsangelegenheiten-berlin-lan geheine-geh.html

Reckwitz, A. (2003). Grundelemente einer Theorie sozialer Praktiken [Basic elements of a theory of social practices]. Zeitschrift für Soziologie, 32(4), 282-301.

Said, E. (2002). Reflections on exile. In Reflections on exile and other essays (pp. 173-186). London: Granta 
Publication.

Sanyal, R. (2010). Squatting in camps: Building and insurgency in spaces of refuge. Urban Studies, 48(5), 877-890.

Sanyal, R. (2014). Urbanizing refuge: Interrogating spaces of displacement. International Journal of Urban and Regional Research, 38(2), 558-572.

Schatzki, T. R. (1996). Social practices: A Wittgensteinian approach to human activity and the social. Cambridge: Cambridge University Press.

Steigemann, A. M. (2018). First arrivals: The sociomaterial development of arrival infrastructures in Thuringia. In B. Meeus, K. Arnaut, \& B. van Heur (Eds.), Arrival infrastructures (pp. 179-205). Basingstoke: Palgrave Macmillan.

Tometten, C. (2018). Resettlement, humanitarian admission, and family reunion: The intricacies of Germany's legal entry regimes for Syrian refugees. Refugee Survey Quarterly, 37(2), 187-203.

United Nations. (2014). 2014 Syria regional response plan: Jordan (Report). Amman: United Nations.

UNHCR. (2007). Handbook for emergencies (third ed.). Geneva: UNHCR.
UNHCR. (2012a). Syria regional refugee response (Report 12 July 2012). Geneva: UNHCR.

UNHCR. (2012b). Syria regional refugee response (Report 27 July 2012). Geneva: UNHCR.

UNHCR. (2013a). One year on: Jordan's Za'atari refugee camp mushrooms into major urban centre. Unhcr.org. Retrieved from www.unhcr.org/ news/latest/2013/7/51f698ee6/year-jordans-zaatarirefugee-camp-mushrooms-major-urban-centre.html

UNHCR. (2013b). Zaatari Governance Plan (UNHCR Paper version 1.3). Geneva: UNHCR.

UNHCR. (2014a). Shelter and settlement strategy, Syrian refugee crisis. Shelter working group-Jordan. Geneva: UNHCR.

UNHCR. (2014b). UNHCR's global shelter and settlement strategy, 2014-2018. Geneva: UNHCR.

UNHCR. (2014c). Za'atari Refugee Camp: 2013 Safety and Security Report. Amman: UNHCR.

Wendel, K. (2014). Unterbringung von Flüchtlingen in Deutschland: Regelungen und Praxis der Bundesländer im Vergleich (Report). Frankfurt am Main: Pro Asyl.

\section{About the Authors}
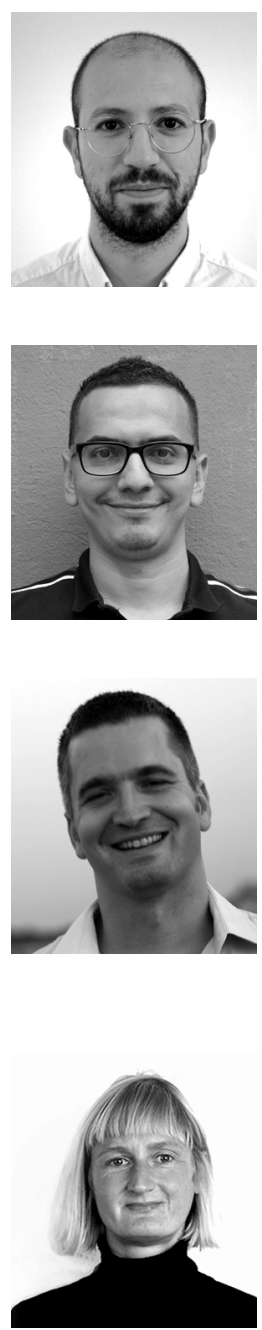

Ayham Dalal is an Architect and Urban Planner based between Berlin and Amman. He has a master's degree in Integrated Urbanism and Design from Stuttgart and Ain Shams Universities in 2014. In 2015, he joined the Department of International Urbanism and Design (Habitat Unit) at the Technical University Berlin as a PhD Candidate. Since 2018, Ayham has worked as a researcher for the "Architectures of Asylum" project that investigates appropriation practices in refugee camps in Jordan and Germany. He is also a Research Fellow at the Institut français du Proche-Orient (IFPO) in Amman and Beirut through the LAJEH project.

Amer Darweesh is an Architect and Urban Planner holding a bachelor's degree in Architecture from the University of Damascus since March 2013. He has worked in urban development projects in IraqErbil and Al Sulaymania-and is currently working at the Berliner Immobilienmanagement, which is one of the actors involved in the planning and designing of the refugee accommodations in Berlin. In addition to teaching at the research studio (Tempohomes), Amer is also finalising his master's thesis, "'Planning for Asylum Accommodation in Berlin", in the master's program Urban Management at the Technical University of Berlin.

Philipp Misselwitz is an Architect and Urban Planner educated at Cambridge University and the Architectural Association London. He completed his PhD in 2009. Since 2013, he has been Chair of the Habitat Unit at Technical University Berlin. His research and practice relate to user-driven and process-oriented planning, participation, and co-production in transformation-to-sustainability processes and urbanisation impact of translocal dynamics such as migration or globalised production. He is the Principal Investigator of "Architectures of Asylum" as part of the DFG-funded Collaborative Research Centre (SFB 1265) "Re-figuration of Space" (2018-2021). He is a consultant to GIZ and the United Nations on refugee camp urbanisation.

Anna Steigemann is an Urban Sociologist who works at the intersection of urban studies and migration research. She has been a Senior Researcher at TU Berlin's Habitat Unit/Chair of International Urbanism and Design since October 2016 and has worked as an Assistant Professor for Urban Planning, Urban Sociology, Social Research, Urban Studies, and Urban Management at Humboldt-University Berlin, TU Berlin, the CUNY Graduate Centre, and Bauhaus-University Weimar before. 